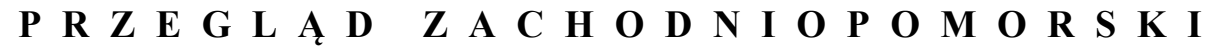 ROCZNIK XXXIV (LXIII) ROK 2019 ZESZYT 3
}

\section{$\begin{array}{lllllllll}A & \mathbf{R} & \mathbf{T} & \mathbf{Y} & \mathbf{K} & \mathbf{U} & \mathbf{L} & \mathbf{Y}\end{array}$}

\author{
MARIA JAREMEK \\ Szczecin \\ e-mail: jaremek6@tlen.pl
}

\section{Dzialalność Karola CZEJARKa - KSIĘGARZA, WSPÓŁORGANIZATORA INSTYTUCJI I SPOŁECZNEGO RUCHU KUlTuralnego NA POMORZU ZaCHODNIM, GERMANISTY, AUTORA LICZNYCH PUBLIKACJI}

Słowa kluczowe: Karol Czejarek, germanista, tłumacz

Keywords: Karol Czejarek, Germanist, translator

VI Sympozjum „Ludzie książki Pomorza Zachodniego” zorganizowane w maju 2018 roku w Książnicy Pomorskiej było doskonałą okazją do przypomnienia sylwetki Karola Czejarka, urodzonego w 1939 roku w Berlinie, a w latach 19481973 mieszkającego w Szczecinie'. Wojna i okres powojenny odegrał w dalszym życiu Karola Czejarka znaczącą rolę.

Celem tego artykułu jest próba przedstawienia działalności zawodowej, społecznej, naukowej, publicystycznej i twórczości translatorskiej Karola Czejarka. Przygotowanie tekstu poprzedzone było korespondencją mailową, rozmowami telefonicznymi, a nade wszystko zapoznaniem się z problematyką przedstawianą w publikacjach Karola Czejarka.

1 Referat o Karolu Czejarku Maria Jaremek wygłosiła 15.05.2018 r. w Książnicy Pomorskiej podczas VI edycji Seminarium „Ludzie książki Pomorza Zachodniego”. 
Artykuł podzielono na dwie części - „okres szczeciński” i „okres warszawski”. Można pokusić się o tezę, że właśnie okres szczeciński był w życiu Karola Czejarka początkiem, który zadecydował o wyborze kierunku studiów i rozpoczęciu kariery zawodowej. Okres warszawski zaś to błyskawiczna kariera zawodowa, naukowa, publicystyczna i translatorska.

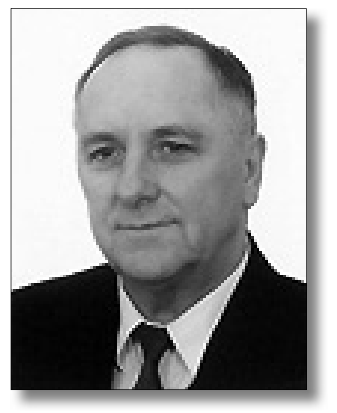

\section{Okres szczeciński}

Rodzina Czejarków pochodzi ze Śląska. Dziadek, Karol Czejarek, polski powstaniec śląski i Anna Czejarek, z domu Widera, mieszkali w Zabrzu, gdzie wnuczek Karol często przebywał².

Ojciec Karola, Roman Czejarek urodził się w 1913 roku w Zabrzu (Hindenburg), w mieście, które de Gaulle - prezydent Francji, kiedy był w Polsce - nazwał jednym z najbardziej polskich miast.

Roman Czejarek po maturze w 1931 roku wyjechał studiować językoznawstwo w Berlinie na Uniwersytecie Fryderyka Wilhelma. Znał biegle sześć języków, pracował jako docent na Uniwersytecie w Berlinie i aktywnie działał w Związku Polaków w Niemczech ${ }^{3}$. W 1933 roku został wyrzucony z uniwersytetu i otrzymał nakaz pracy w kopalni w Giesen. Pięć lat później zamieszkał w niewielkiej

2 W tej rodzinie tradycją było nadawanie imion dzieciom płci męskiej po dziadku. Stąd pojawiają się w tym materiale na przemian imiona Karol i Roman.

3 Związek Polaków w Niemczech, organizacja polonijna założona w 1922 r. w Berlinie. W marcu 1938 r. podczas I Kongresu Związku Polaków spod znaku „Rodła” (odbył się w Theater des Volkes) w Berlinie, uchwalono Pięć prawd Polaka, które stanowiły ideową postawę działalności związku. ZPwN prowadził działalność kulturalną, gospodarczą i polityczną, miał swoich reprezentantów w Sejmie pruskim, sejmikach krajowych i radach miejskich. 27 lutego 1940 roku związek został zdelegalizowany, a jego majątek skonfiskowany. Po wojnie związek został reaktywowany i wznowił działalność w zachodniej części Niemiec. Wikipedia /poloniaviva.eu/index.php/pl/organizacje/1556-rodlo (dostęp 20.09.2018). 
miejscowości Ahrbergen, leżącej między Hanowerem a Hildesheim, gdzie poznał i poślubił Marie Mellin. Młode małżeństwo zamieszkało w Berlinie i tam, 11 sierpnia 1939 roku urodził się im syn Karol.

W 1941 roku Roman Czejarek został wcielony do Wermachtu i walczył na froncie pod Stalingradem, skąd udało mu się uciec. Dzięki znajomości m.in. języka rosyjskiego znalazł się później w angielskiej niewoli. Po II wojnie światowej Roman Czejarek pracował w Polskiej Misji w Niemczech.

W 1948 roku Marie i Roman Czejarkowie wraz z dwójką dzieci zamieszkali w Szczecinie. Tutaj ich dzieci - 9-letni Karol i młodsza o 5 lat siostra Annemarie (po babci Anne, po matce Marie) uczęszczały do szkoły. W domu, i w tym „berlińskim” i w późniejszym „szczecińskim”, rodzina mówiła wyłącznie po polsku. Nie był to okres sprzyjający rodzinie Czejarków. Uprzedzenia do nazistowskich Niemców, sprawców okrutnej wojny, świeże, niezabliźnione i trudno gojące się rany rzutowały na ogólne stosunki mieszkańców Szczecina. Roman Czejarek liczył na posadę w Akademii Handlowej, jednak dla ówczesnej władzy był politycznie podejrzany. Nie mogąc realizować się w swoim zawodzie, pracował na podrzędnych stanowiskach w Szczecińskim Urzędzie Morskim i Zarządzie Portu, potem w Zakładach Doskonalenia Rzemiosła, a swoją karierę zakończył w Wojewódzkim Zarządzie Aptek. Roman Czejarek zmarł w listopadzie 1953

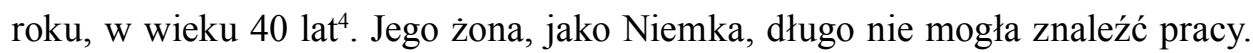
Syn, uczeń szkoły średniej, pomagał matce, udzielając korepetycji i podejmował się różnych prac fizycznych. W 1957 roku matka wróciła z córką Annemarie do swojego rodzinnego Ahrbergen ${ }^{5}$. Po jej wyjeździe, młodym Karolem zaopiekowała się rodzina Stanisława Polaka. „Było nam bardzo ciężko” - wspominał Karol Czejarek. Przez całe lata ojciec wielokrotnie mu powtarzał: „Pamiętaj, że prawdziwym Polakiem jest się wtedy, gdy żyje się w kraju, myśli i czuje po polsku, i codziennie służy ojczyźnie uczciwą pracą". Syn Karol pozostał w Polsce, w Szczecinie, bo nie wyobrażał sobie, aby mogło być inaczej ${ }^{6}$. Uczęszczał do męskiego Liceum Ogólnokształcącego nr II w Szczecinie, od nazwy ulicy zwanego „Pobożniakiem”. W tym czasie aktywnie trenował kolarstwo i Klub Sportowy „Arkonia” przyznał mu stypendium sportowe. Karol ukończył szkołę

${ }^{4}$ Zmarł w szpitalu po operacji żołądka, na zapalenie płuc.

5 Po jakimś czasie wyszła tam ponownie za mąż.

${ }^{6}$ Prof. Karol Czejarek często odwiedza grób ojca i groby innych bliskich mu szczecinian, m.in. prof. Jana Szyrockiego, Karola Koczego, Stanisława Polaka, jego żony i syna Tadeusza, którzy zaopiekowali się nim po wyjeździe matki do Niemiec. 
w 1956 roku, ciepło wspominał dyrektora Henryka Kańskiego, od którego za bardzo dobrą naukę otrzymał stypendium. O sobie mówił, że w szkole był raczej uczniem wzorowym, działał w samorządach klasowych i szkolnych, ale zdarzyło mu się opuścić akademię „Ku czci rewolucji” (gdy nie zwolniono go z niej na trening), i po której o mało nie wyleciał ze szkoły, miał obniżoną ocenę z zachowania i odebrano mu wtedy stypendium. W latach pięćdziesiątych młody polonista Erazm Kuźma swoimi porywającymi wykładami wprowadzał uczniów w świat kultury, filozofii, literatury ${ }^{7}$. Oto fragment wspomnienia o ulubionym poloniście, które Karol Czejarek zawarł po latach w eseju Na świat patrzeć sercem:

Był nauczycielem (i wychowawcą) niezwykłym, uwielbianym; próbowaliśmy Go naśladować. Zapraszał na lekcje pisarzy, aktorów, artystów malarzy, scenografów; ludzi, którzy mieli zasługi w tym, co wówczas i dziś nazywa się „Szczecińskie” (pisane przez duże „S”). Potem, gdy już pracowałem w STK (Szczecińskim Towarzystwie Kultury), a On był prezesem szczecińskiego okręgu Związku Literatów Polskich, godzinami zastanawialiśmy się, jak umacniać i rozwijać „młode” jeszcze wówczas środowisko literackie; jak dążyć do powstania Uniwersytetu Szczecińskiego, kształtować miejscowe środowisko humanistyczne i wiązać absolwentów wyższych uczelni z regionem. (...) To Jemu należy zawdzięczać m.in. szczecińskie zjazdy pisarzy Ziem Zachodnich i Północnych (także pisarzy-marynistów); to On był duszą „,spotkań z literaturą” organizowanych swego czasu w całym województwie; „gwiazdą” Klubu Bibliofilów w Księgarni „Klubowa”, której byłem wówczas kierownikiem ${ }^{8}$.

Karol Czejarek w tym eseju dodał, że profesor Erazm Kuźma, obok Romana Łyczywka, Hanny Skinder, Władysława Daniszewskiego, Karola Koczego, Stanisława Krzywickiego, Gerarda Labudy, Wiesława Rogowskiego należał do osób zasłużonych dla rozwoju kultury w mieście i regionie. W 2016 roku obchodzono Jubileusz 75-lecia II Liceum Ogólnokształcącego. Zjazd absolwentów był okazją do podzielenia się wspomnieniami o swoich ulubionych nauczycielach?

7 Profesor Erazm Kuźma zginął tragicznie potrącony przez samochód 21.03.2014 r., miał 88 lat. Na łamach „Kuriera Szczecińskiego” wspominali Go m.in. Bogdan Twardochleb i Artur Daniel Liskowacki. Karol Czejarek poświęcił mu obszerny esej Na świat patrzeć sercem, „Gazeta Wyborcza, Magazyn Szczeciński”, 4.04.2014, s. 9.

8 Tamże.

9 Anons o zbliżającym się Zjeździe w dniach 18 i 19.11.2019 r. zamieścił „Kurier Szczeciński” nr 221, 16.11.2016; wspomnienia absolwentów „Pobożniaka” zostały zamieszczone w „Kurierze Szczecińskim” nr 223, 18-20.11.2016. 
Po tej dygresji, należy powrócić do początków życia kulturalnego Szczecina, które po wojnie zaczęło się prężnie odradzać. W 1945 roku, do zrujnowanego miasta zaczęli przybywać pierwsi osadnicy, wśród których była silna grupa byłych więźniów obozu koncentracyjnego Mauthausen-Gusen. 17 czerwca 1945 roku przedstawiciele byłej grupy więźniów w składzie: Leon Królak, Wincenty Szałek, Czesław Piskorski, Franciszek Belling, Marian Sławiński, Stefan Niewiada założyli

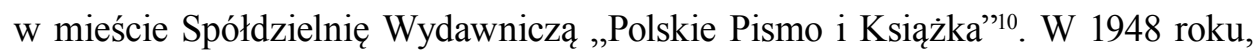
w Szczecinie, liczącym wówczas 73 tys. mieszkańców, było aż 11 księgarńn ${ }^{11}$.

W styczniu 1950 roku upaństwowiono niemal wszystkie prywatne księgarnie i powstało Państwowe Przedsiębiorstwo „Dom Książki”, którego siedziba mieściła się w Szczecinie, najpierw przy pl. Żołnierza Polskiego 2, później przy al. Wojska Polskiego 29, a następnie dyrekcję przedsiębiorstwa przeniesiono do okazałego gmachu przy ul. Królowej Korony Polskiej 24. Pierwszym dyrektorem „DK” był Zygmunt Mieszkowski zatrudniony w latach (1950-1951). Jednym z najmłodszych dyrektorów w latach 1951-1952 w tej branży w Polsce był 26-letni Andrzej Teofil Polaczek $^{12}$, po którym funkcję tę pełnili: Stefan Piotrowski (1953-1954) i Marian Dybus (1954-1956), a także mgr ekonomii Janusz Sułkowski (1957-1990)13.

Ostatnim dyrektorem P.P. „DK” w latach 1990-1997 w Szczecinie był Ryszard Piątek.

Pierwszą pracę Karol Czejarek rozpoczął zaraz po maturze 1 sierpnia 1956 roku w księgarni „Klubowej” przy al. Jedności Narodowej 5, gdzie przeszedł wszystkie stopnie księgarskiej hierarchii i po jakimś czasie został zastępcą, a potem kierownikiem księgarni. Jednocześnie studiował zaocznie księgarstwo w Szkole Handlowej w Poznaniu, a po odbyciu czynnej służby wojskowej (19591961) - germanistykę na UAM w Poznaniu. W „Domu Książki” pracował 10

${ }^{10}$ Do grupy członków-założycieli należeli również: Marian Kwintkiewicz, Marian Małolepszy, Stefan Pełczyński i Stefan Mróz. W późniejszym okresie dołączyli: Zenon Niewiada, Irena Kaczorowska-Szałek i Zygmunt Mieszkowski.

${ }^{11}$ Zainteresowanych powstawaniem pierwszych księgarń prywatnych w powojennym Szczecinie odsyłamy do najnowszej Encyklopedii Szczecina, Encyklopedia Szczecina, Wydanie jubileuszowe z okazji 75-lecia polskiego Szczecina, Szczecińskie Towarzystwo Kultury, Szczecin 2015, s. 496-497.

${ }^{12}$ Informację o latach pracy dyr. Andrzeja Teofila Polaczka przekazała jego córka Elżbieta Ankutowicz, która w późniejszych latach także pracowała w „DK”. A.T. Polaczek brał udział W walce niepodległościowej w „Batalionach Chłopskich” pod pseudonimem „Komar”.

${ }^{13}$ Dyr. Janusz Sułkowski wykładał nowy przedmiot „bibliografia” w utworzonym w 1968 r. Technikum Księgarskim przy ówczesnym Technikum Handlowym, późniejszym Liceum Ekonomicznym nr 1 w Szczecinie. Zmarł nagle w 1990 r., tuż przed przejściem na emeryturę. 
lat, do stycznia 1966 roku. Kultura i oświata stały się priorytetem w jego działaniu. Przez kilka lat współpracował z Henrykiem Malickim, który wtedy był kierownikiem księgarni, po nim szefem księgarni „Klubowej” został Karol Czejarek, i wtedy właśnie zainicjował założenie Szczecińskiego Klubu Bibliofilów, do którego, oprócz księgarzy, należała elita środowiska kulturalnego, naukowego i dziennikarskiego: prawnicy, lekarze, artyści, naukowcy, dziennikarze. Karol Czejarek był gospodarzem tych spotkań i łącznikiem klubu z władzami miasta. Stanisław Krzywicki, sekretarz Szczecińskiego Towarzystwa Kultury zaakceptował pod względem formalno-prawnym powstanie Klubu Bibliofilów przy księgarni „Klubowej”. Przyjazny klimat w księgarni służył spotkaniom i dyskusjom nad kondycją kultury. W Klubie odbywały się regularne spotkania autorskie „Biesiady Karola Czejarka”, o czym w 1965 roku poinformował Jaromir Trygław, dziennikarz z „Kuriera Szczecińskiego” ${ }^{44}$ :

W „Klubowej” - nie bez kozery przecież przybrała księgarnia taką nazwę - odbywają się randki szczecińskich autorów z czytelnikami. Tak, właśnie randki! Bo są to spotkania jak najbardziej intymne, w klimacie skłaniającym obie strony do wzajemnych zwierzeń. (...) Tu także na pogawędki z klientami przychodzą: naukowcy, ekonomiści i prawnicy, historycy i historycy sztuki. Co roku w tej osobliwej księgarskiej oficynie odbywają się tradycyjne koncerty absolwentów szczecińskich szkół muzycznych. (...) Karol Czejarek był chyba najmłodszym księgarskim pryncypałem w całej Polsce. Gdy stanął na tym stanowisku miał zaledwie dwadzieścia dwa lata, dzisiaj ma nie więcej jak dwadzieścia sześć, księgarnia bądź co bądź, posiada dziewięć osób personelu.

W dalszej części tekstu autor podkreśla:

Umiejętności młody kierownik księgarni nauczył się już w szkole, w popularnym szczecińskim „Pobożniaku”, od swego polonisty, a dzisiaj przez to najmilszego uczestnika biesiad w „Klubowej” - nam zaś znanego krytyka literackiego - p. Erazma Kuźmy. Więc swoje powołanie - mówi - odkrył już w szkole, w szkolnej bibliotece. Dlatego bezpośrednio po maturze, nie bacząc na niskie uposażenie, stanął za ladą księgarską. (...) Cel, jaki postawili sobie członkowie Klubu: potrzeba oddziaływania kulturalnego na środowisko, skupienie wokół siebie ludzi pełnych inicjatyw i zapału a przede wszystkim pokazanie twórców szczecińskich, jest z powodzeniem realizowany ${ }^{15}$.

14 „Kurier Szczeciński”, 4.08.1965.

${ }^{15}$ Tamże. 
Z dalszej relacji prasowej dowiadujemy się, że w księgarni „Klubowej” odbyły się spotkania z literatami: Ireneuszem Szmidtem, Jerzym Pachlowskim, Ryszardem Liskowackim, Heleną Raszką. Byli tam również autorzy: Julian Stryjkowski, Andrzej Kijowski, Jerzy Waldorff, Jerzy Sztaudynger, Leszek Kołakowski.

Organizowano w księgarni wystawy numizmatyczne, wystawy nowości książkowych, np. wydawnictw muzycznych, prawniczych z oficyny UAM, wydawnictw lekarskich (PZWL), wystawy rocznicowe, jubileuszowe. O oprawę plastyczną i wystrój wnętrz dbał Bogdan Gustowski, plastyk z „DK”, który był najdłużej pracującym fachowcem w branży księgarskiej w Szczecinie (pracował w latach 1959-2001). Był kierownikiem pracowni plastycznej podlegającej pod

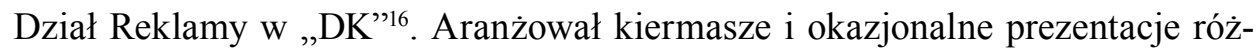
nych wydawnictw. W archiwum prywatnym Bogdana Gustowskiego zachowało się kilkadziesiąt wspaniałych zdjęć z przygotowanych przez niego wystaw. Jednocześnie jako plastyk dbał o dokumentowanie własnego dorobku. Prowadził kronikę działalności Stowarzyszenia Księgarzy Polskich ${ }^{17}$, a siedem tomów przekazał kilka lat temu do Działu Pomorzoznawczego Książnicy Pomorskiej. Dzięki jego postawie zachowały się pokaźne archiwalia z działalności księgarskiej. Kroniki te stanowią cenne źródło dla badaczy na temat działań obrotu i upowszechniania książki, promowania czytelnictwa i rozwoju bibliotek na Pomorzu Zachodnim.

Karol Czejarek ożenił się z Janiną Nowak, pracującą w księgarni przy pl. Zgody, a później razem pracowali w księgarni „Klubowej”. W październiku 1966 roku urodził się ich syn Roman - w przyszłości znany dziennikarz radiowy, publicysta, popularyzator Szczecina i Pomorza Zachodniego. Dwa lata później Karol Czejarek ukończył studia zaoczne na wydziale germanistyki na UAM. Równocześnie prowadził kilka stałych rubryk w szczecińskich gazetach, m.in. w „Głosie Szczecińskim”, „Zza Odry i Łaby”.

W spotkaniach Klubu Bibliofilów, oprócz Gerarda Labudy, Benona Miśkiewicza i Romana Łyczywka, uczestniczył któryś z urzędników KW PZPR, zaproszony przez Karola Czejarka. Był to, jak podkreślił w jednej z rozmów Karol Czejarek, zamierzony zabieg, w celu zintegrowania środowiska społeczno-kulturalnego z władzami politycznymi i pozyskania środków na działalność innych

${ }^{16}$ Razem z Bogdanem Gustowskim w latach 1967-1987 pracowała, jako plastyk dekorator, malarka Bogumiła Szymkowska (zmarła 12.07.2019 r.).

${ }^{17}$ Większoośc księgarzy, szczególnie kierowników księgarń, należała do szczecińskiego oddziału Stowarzyszenia Księgarzy Polskich. 
tworzących się towarzystw w regionie. 1 stycznia 1966 roku Karol Czejarek otrzymał propozycję pracy w Szczecińskim Towarzystwie Kultury (gdzie pracował do 1970 r.). W latach 1964-1971 prezesem STK był Marian Łempicki (przewodniczący Powiatowej i Miejskiej Rady Narodowej). Podczas II Sejmiku Ziemi Szczecińskiej wybrano Karola Czejarka na sekretarza Zarządu Szczecińskiego Towarzystwa Kultury ${ }^{18}$. Aktywna działalność Karola Czejarka w STK była inspiracją dla działaczy terenowych z całego województwa do powoływania podobnych towarzystw społecznych w swoich powiatach oraz podejmowania badań nad przeszłością własnych regionów, co owocowało opracowywaniem kolejnych publikacji. Plonem tych inicjatyw były publikacje zwarte, np. serie: „Z dziejów Ziemi Stargardzkiej”, „Z dziejów Ziemi Chojeńskiej”, „Z dziejów Ziemi Nowogardzkiej”, „Z dziejów Ziemi Łobeskiej” i in., a także wychodzące periodyki, takie jak: „Zeszyty Pyrzyckie”, „Rocznik Kamieński”, „Ziemia Gryficka”.

Sekretarz Zarządu Karol Czejarek na bieżąco prowadził Kronikę STK, dokumentując wszystkie podejmowane inicjatywy kulturalne i społeczne w całym regionie. Należy podkreślić, że STK i inne stowarzyszenia terenowe funkcjonowały i działały w ówczesnej, wcale niełatwej rzeczywistości politycznej i ideologicznej. W latach 1970-1973 Karol Czejarek pełnił kierownicze stanowisko w Wydziale Kultury Prezydium Wojewódzkiej Rady Narodowej w Szczecinie. Współorganizował sejmiki kultury miłośników Ziemi Szczecińskiej i sesje Wojewódzkiej Rady Narodowej w celu stworzenia bazy materialnej dla kultury i szczecińskich instytucji artystycznych. Poprzez STK angażował się w organizację różnych imprez artystyczno-kulturalnych: m.in. współorganizował Zjazd Pisarzy Ziem Zachodnich i Północnych, Pisarzy Marynistów, Festiwal Poezji im. Konstantego Ildefonsa Gałczyńskiego, Festiwal Krótkometrażowych Filmów Morskich $^{19}$, Festiwal Współczesnego Malarstwa Polskiego. Działał też w komitetach organizacyjnych Międzynarodowego Festiwalu Muzyki Organowej i Kameralnej w Kamieniu Pomorskim i Międzynarodowego Festiwalu Pieśni Chóralnej w Międzyzdrojach, zainicjowanego w 1966 roku przez Jana Szyrockiego.

Karol Czejarek wiele uwagi poświęcił imprezie, którą zainaugurował w 1969 roku. Rozpisano wówczas konkurs pamiętnikarski „Dzieje szczecińskich rodzin

${ }^{18}$ Przed Karolem Czejarkiem dyrektorami biura STK i sekretarzami byli: Stanisław Krzywicki w latach 1964-1966 i Henryk Kidawa w latach 1966-1970.

${ }^{19}$ W 1957 r. powołano Towarzystwo Miłośników Telewizji, którego prezesem został sędzia Zenon Zaniewicki, który był głównym pomysłodawcą Festiwalu Krótkometrażowych Filmów Morskich i Klubu Marynistów. 
XX wieku”. Miało to być jednorazowe przedsięwzięcie, zachęcające mieszkańców Szczecina i regionu do spisywania swoich losów. Niemal całkowita wymiana ludności powojennego Szczecina sprawiła, że zaszła potrzeba spisania takich wspomnień. W 1970 roku na konkurs wpłynęło aż 191 prac. Postanowiono więc, że konkurs będzie kontynuowany. Trwa on, z przerwą, od ponad 40 lat i do tej pory zgromadzono ok. 1000 pamiętników. Prace te, bardzo obszerne, choć często nacechowane subiektywizmem stanowią dla historyków i innych badaczy nieocenione źródło wiedzy o codziennym życiu w regionie w latach powojennych i obecnych. Cieszy, że na konkurs swoje wspomnienia wysłali i zostali docenieni m.in. dwaj szczecińscy księgarze Edward Szczęsny ${ }^{20}$ (Nagroda 1980, Wyróżnienie 1986) i Bronisław Maliszewski (II Nagroda 1993) ${ }^{21}$.

W 2009 roku z okazji 45-lecia Szczecińskiego Towarzystwa Kultury i 40-lecia konkursu „Dzieje szczecińskich rodzin XX wieku” została wydana publikacja Pamiętnikarstwo na Pomorzu Zachodnim. Czterdziestolecie konkursu „Dzieje szczecińskich rodzin"22. Cecylia Judek na stronach tej jubileuszowej publikacji poinformowała, iż największą liczebnie grupą pamiętników zgromadzonych w Sekcji Rękopisów Działu Zbiorów Specjalnych Książnicy Pomorskiej stanowią właśnie wspomnienia nadesłane na konkurs „Dzieje szczecińskich rodzin w XX wieku”. Plonem wspomnień jest kilkadziesiąt zwartych publikacji autorskich, laureatów tego konkursu ${ }^{23}$.

Swoim zaangażowaniem Karol Czejarek przyczynił się także do powstania Teatru Muzycznego na Zamku oraz regionalnych towarzystw społeczno-kulturalnych, rozwoju ognisk artystycznych i szkolnictwa artystycznego, środowisk twórczych i wydawnictw regionalnych. Był rzecznikiem powstania Punktu Konsultacyjnego Uniwersytetu Poznańskiego w Szczecinie.

Wiceministrem kultury i sztuki w latach 1972-1978 był Tadeusz Kaczmarek, który w 1972 roku, przy okazji wizyty w Szczecinie, zobowiązał się do kontynuowania odbudowy Zamku Książąt Pomorskich (deklarując w imieniu

\footnotetext{
${ }^{20}$ Referat Edward Szczęsny (1920-1989) księgarz i kronikarz przedstawiła w 2015 r. w Książnicy Pomorskiej Aleksandra Skiba, pracownica tej instytucji.

${ }^{21}$ Bronisław Maliszewski, zatrudniony w ”DK” od 1949 r., kierownik Księgarni „Zamkowej”, wykładowca w Technikum Księgarskim przy Technikum Handlowym.

${ }^{22}$ Pamiętnikarstwo na Pomorzu Zachodnim. Czterdziestolecie konkursu „Dzieje szczecińskich rodzin”, red. T. Białecki, K. Kozłowski, A. Derbisz, S. Krzywicki, U. Rosłaniec, Szczecin 2009.

${ }^{23}$ Tamże, wykaz zwartych publikacji autorskich laureatów konkursu „Dzieje szczecińskich rodzin", s. 50-52.
} 
Ministerstwa Kultury i Sztuki dodatkowe środki, zwłaszcza na umieszczenie w nim teatru muzycznego, dziś opery) i nadania Muzeum Pomorza Zachodniego oraz Wojewódzkiej Bibliotece Publicznej statusu instytucji narodowych. Łączyło się to też z przyznaniem dodatkowych środków finansowych na rozbudowanie sieci bibliotek publicznych, księgarń, domów kultury, ognisk artystycznych, co znacznie przyspieszyło tworzenie na terenach odzyskanych po drugiej wojnie światowej - nowych, polskich tradycji kulturalnych.

Oprócz wielu funkcji społecznych Karol Czejarek realizował własne zainteresowania, o czym wcześniej wspomniano. W latach 1957-1963 był wielokrotnym mistrzem kolarskim na torze i szosie; zdobywając m.in. mistrzostwo (juniorów) Polski i wicemistrzostwo (seniorów) na torze w jeździe drużynowej na 2 i 4 tys. m. Zdobył też kilkakrotnie mistrzostwo Szczecina i okręgu na szosie i na torze m.in. na $1 \mathrm{~km}$ (wygrywając ze słynnym Zbigniewem Zającem), w wyścigu na 100 okrążeń toru pokonał reprezentantów Polski m.in. Jerzego Beka, Stefana Borucza, Lucjana Józefowicza ${ }^{24}$.

Wspaniała działalność zawodowa i społeczna Karola Czejarka w Szczecinie została zakończona, a właściwie przerwana w 1973 roku. Przyjazd jego siostry i szwagra z NRF w odwiedziny do Szczecina, wojewódzkie władze partyjne uznały za wykroczenie i musiał wyjechać do Warszawy. Długo jeszcze po przyjeździe do Warszawy „tłumaczył się”, dlaczego (po śmieci ojca) nie wyjechał wraz z matką i siostrą do Niemiec, lecz pozostał w kraju.

\section{Okres warszawski}

Pracę w Ministerstwie Kultury i Sztuki zaproponował Karolowi Czejarkowi ówczesny wiceminister Tadeusz Kaczmarek, ale nie został tam zatrudniony, i ostatecznie 1 października 1973 roku otrzymał stanowisko wicedyrektora Składnicy Księgarskiej. Bezpośrednim jego przełożonym był Bronisław Palimąka ${ }^{25}$, a dyrektorem Zjednoczenia Księgarstwa - Kazimierz Majerowicz ${ }^{26}$, któremu podlega-

\footnotetext{
${ }^{24}$ Karol Czejarek został zaproszony wraz z żoną na „Spotkanie kolarskich pokoleń” w Szczecinie. Publikacja Karola Czejarka o tym spotkaniu na stronie przegląddziennikarski. pl. 8.06.2019.

${ }^{25}$ Bronisław Palimąka, wieloletni dyrektor P.P. Składnicy Księgarskiej. Od 1962 r. był przewodniczącym Zarządu Głównego SKP. Zmarł 27.02.2008 r.

${ }^{26}$ Kazimierz Majerowicz (1920-2005) wybitny księgarz, wieloletni dyrektor naczelny Centrali Księgarstwa, wieloletni szef Wydawnictw Artystycznych i Filmowych. ,Jerzy Wittlin mawiał, że gdyby nie Kazimierz Majerowicz, ani nie znalazłby środków, ani nie przekonałby decydentów do edycji reprintów, które w latach 70. i 80. XX w. stały się wizytówką
} 
li dyrektorzy wszystkich oddziałów „Domu Książki”. W Składnicy Księgarskiej Karol Czejarek pracował do 15 października 1977 roku. Prezesem Zjednoczenia Księgarstwa i jednocześnie szefem Reklamy i Upowszechniania Księgarstwa był Tadeusz Hussak, który w latach 1986-1989 pełnił funkcję zastępcy dyrektora Zjednoczenia Księgarstwa ${ }^{27}$.

Dzięki wielu inicjatywom upowszechniania książki Karol Czejarek szybko awansował. Od października 1977 do marca 1981 roku pracował w Centralnym Ośrodku Upowszechniania Kultury, gdzie piastował funkcję dyrektora. W tym samym roku objął stanowisko dyrektora Departamentu Plastyki w Ministerstwie Kultury i Sztuki. Pracował tam ponad trzy lata, do końca grudnia 1984 roku. W styczniu 1985 roku był już dyrektorem Wydziału Kultury Urzędu Miasta. Gdy ministrem Kultury i Sztuki był Aleksander Krawczuk, awansowano go w 1988 roku na dyrektora Departamentu Książki w tym ministerstwie, i pełnił tę funkcję do 31 sierpnia 1990 roku.

Działaczem partyjnym - jak twierdzi - nigdy nie był, choć były to wszystkie stanowiska tzw. nomenklaturowe. Gdy ministrem kultury i sztuki został Kazimierz Dejmek i zaproponował mu tekę wiceministra - Karol Czejarek jej nie przyjął.

W 1990 roku, na Wydziale Humanistycznym Uniwersytetu Szczecińskiego Karol Czejarek obronił pracę doktorską Proza Anny Seghers: problematyka bohatera zaangażowanego (Prosa von Anna Seghers. Problematik und Typus eines engagierten Helden). Od tego momentu właściwie rozpoczął się drugi rozdział jego życia zawodowego. Podążanie drogą wytyczoną przez ojca było tylko kwestią czasu; wszystko wskazywało, że docelowo, w Warszawie zajmie się germanistyką i dydaktyką nauczania języka niemieckiego, tłumaczeniami oraz pracą na rzecz niemiecko-polskiego pojednania.

W 1990 roku został zatrudniony na Uniwersytecie Warszawskim jako wykładowca w Nauczycielskim Kolegium Języka Niemieckiego, a od 1 października 1994 aż do przejścia na emeryturę (w maju 2016) był adiunktem, i kierownikiem Zakładu Kulturoznawstwa Stosowanego w Instytucie Lingwistyki Stosowanej

WAiF, a niektóre z nich, jak „Herbarz Polski” ks. Kacpra Niesieckiego, osiągnęły status bestsellerów", strona internetowa: Kazimierz Majerowicz - Archiwum.

${ }^{27}$ Tadeusz Hussak (1919-2014) - księgarz, działacz społeczny prezes SKP, autor. Pracował w wydawnictwie „Czytelnik” na stanowisku kier. Klubów Literackich. Pracował w centrali „Domu Książki” i równolegle jako wykładowca w Technikum Księgarskim im. S. Żeromskiego w Warszawie oraz w Instytucie Bibliotekoznawstwa UW. Od 2005 r. był członkiem ZLP. https://wikipedia.org/wiki/Tadeusz_Hussak (dostęp 18.02.2019). 
Uniwersytetu Warszawskiego. Równolegle z pracą na UW i w Akademii Humanistycznej im. Aleksandra Gieysztora w Pułtusku, był też nauczycielem języka niemieckiego w liceach.

Ojciec Karola Czejarka chciał, by syn uczył się gry na skrzypcach, ale on wolał jeździć na rowerze i grać w piłkę. Za to studiował, i podobnie jak on, kontynuował niemcoznawcze zainteresowania.

Wiele artykułów autorstwa Karola Czejarka opublikowanych jest na stronach: pisarze.pl, Przegląd Dziennikarski.pl, ORE Edukator. Jego artykuły i recenzje zamieszczane są m.in. w „Colloquia Germanica Stetinensia” i od czasu do czasu w codziennej prasie szczecińskiej.

Karol Czejarek jest autorem książek: Anna Seghers (1986); Nazizm, wojna i III Rzesza w powieściach Hansa Hellmuta Kirsta (2003); antologii utworów o tematyce wojennej - Sonata wiosenna (1982). Z Joanną Słocińską opracował publikację Gramatyka niemiecka dla ciebie (2000). Jest tłumaczem (wspólnie z synem Hubertem) Collins German Grammar i Collins German Verb (2001/2002); współautorem książki Polen - Land und Leut (1989). Jest też redaktorem licznych książek w tym: Polska między Niemcami a Rosja (2011), Historia pamięcia pisana. Biografie polsko-niemieckie, cz. 1 (2014) i cz. 2 (2017).

We wspomnieniach autor często wraca do swojej pierwszej publikacji Anna Seghers, książki, która była tematem pracy doktorskiej. Z dumą podkreśla, że na jego rozprawie doktorskiej był obecny jego ukochany polonista profesor Erazm Kuźma. Ta publikacja jest szkicem monograficznym o twórczości pisarki Anny Seghers, urodzonej w 1900 roku w Moguncji, przedstawicielki młodego pokolenia Niemiec, laureatki nagrody im. Heinricha Kleista w 1928 roku. Nagrodę otrzymała za swój debiutancki utwór Bunt rybaków z Santa Barbara. Wcześniej otrzymywali ją renomowani pisarze, tacy jak Bertold Brecht i Arnold Zweig. Po II wojnie światowej zaliczana była do czołowych przedstawicieli literatury Niemieckiej Republiki Demokratycznej. Z monografii o Annie Seghers dowiadujemy się, że w 1948 roku uczestniczyła w Kongresie we Wrocławiu. Zaprzyjaźniła się m.in. z Jerzym Putramentem, Janem Edmundem Osmańczykiem. W 1977 roku A. Seghers otrzymała tytuł doktora honoris causa Uniwersytetu w Moguncji ${ }^{28}$.

Znaczący dorobek naukowy Karola Czejarka stanowią także dokonania translatorskie. O tym, jak trudna jest praca tłumacza - przekonuje w swojej książce Zofia Zaleska: „Dobry tłumacz okazuje się sprawnym sługą dwóch panów

\footnotetext{
${ }^{28}$ Anna Seghers zmarła po ciężkiej chorobie 1.06 .1983 r., w wieku 77 lat.
} 
- języka oryginału i języka przekładu, udaje mu się wybrnąć szczęśliwie z sytuacji bez wyjścia"29. Na miano takiego oddanego tłumacza zasługuje Karol Czejarek, szczególnie zafascynowany Dziełami zebranymi Hansa Hellmuta Kirsta, jednego z najbardziej znanych pisarzy niemieckich po 1945 roku.

W latach 1945-1946 Hans Hellmut Kirst przez dziewięć miesięcy przebywał w amerykańskim obozie dla internowanych w Garmisch. Po zwolnieniu (nie udowodniono mu żadnych czynów zbrodniczych) zajął się pracą i pisaniem. Jest autorem pięcioksięgu: „08/15” w koszarach, „08/15” na wojnie, „08/15” walczy do końca, „08/15” dzisiaj, „08/15” w partii. W Polsce, gdy tylko ukazała się jego trylogia (w pierwszym przekładzie Jacka Fruehlinga), uzyskał od razu niebywałą popularność. Dwa ostatnie tomy pięcioksięgu, czyli „08/15” dzisiaj oraz „,08/15” w partii przetłumaczył Karol Czejarek w latach 2000-2001 w wydawnictwie Libros (Świat Książki), należącym do Grupy Bertelsmanna ${ }^{30}$.

Hans Hellmut Kirst łącznie napisał ponad 50 powieści. Szczytowym jego osiągnięciem jest książka Noc dtugich noży $y^{31}$. Jest to powieść o metodach i mechanizmach nazistowskiej władzy, jakimi udało się Hitlerowi ogłupić i uwieść, a w konsekwencji zniszczyć i unicestwić własny naród. W ten sposób Hans Hellmut Kirst odsłonił kulisy holokaustu, obozów śmierci i mechanizmy, które doprowadziły do II wojny światowej. Obnażył Niemców i przedstawił realia tamtych ponurych czasów. Podobną rangę mają w jego twórczości powieść Fabryka oficerów, Noc generatów ${ }^{32}$ i ostatnia przetłumaczona przez Karola Czejarka Rok 1945 - Koniec ${ }^{33}$. Ogółem Karol Czejarek przetłumaczył dotąd siedem powieści Hansa Hellmuta Kirsta, i jak zapewnia, nie poprzestaje na tym. Jest zdania, że nikt inny, tak jak on, nie ujawnił tajemnic III Rzeszy.

Obok prac translatorskich, późniejszy okres swojej działalności Karol Czejarek poświęcił sprawom wypędzenia i przesiedlenia. Ten problem stał się dla niego najważniejszym polem badań. Będąc długoletnim sekretarzem zarządu byłego Międzywydziałowego Centrum Badań Niemcoznawczych w Pułtusku,

${ }^{29}$ Z. Zaleska, Przejęzyczenie. Rozmowy o przekładzie, Wołowiec 2016, s. 5.

${ }^{30}$ H.H. Kirst, Rok 1945 - koniec, tłum. K. Czejarek, Warszawa 1993; tenże, Mene, tekel (Wojna z Polska), tłum. K. Czejarek, Warszawa 1993; tenże, Pies i jego pan. Opowieść o przyjacielu, tłum. K. Czejarek, Warszawa 1994.

${ }^{31}$ H.H. Kirst, Noc dlugich noży, tłum. K. Czejarek, Warszawa 2000.

${ }^{32}$ H.H. Kirst, Noc generałów, tłum. K. Czejarek, Warszawa 2001.

${ }^{33}$ H.H. Kirst, Rok 1945 - koniec; tenże, Ratuj się kto może i Chaos upadku, t. 1, 2, tłum. K. Czejarek, Warszawa 1993. H.H. Kirst zmarł 23.02.1989 r. w Bremie. 
współpracował z niemieckim stowarzyszeniem ost-west-forum Gut Gödelitz, którego przewodniczącym był Axel Schmidt-Gödelitz. Przedstawiciele obu stron intensywnie zabiegali o wzajemne i dobre polsko-niemieckie i niemiecko-polskie relacje. W tym celu odbyły się dwie konferencje, jedna w Gut Gödelitz w Saksonii, a druga w Akademii Humanistycznej w Pułtusku. W efekcie tych spotkań powstała dwujęzyczna publikacja Historia pamięcia pisana. Biografie polsko-niemieckie (cz. 1) $)^{34}$, z 38 polsko-niemieckimi biografiami, które, jak zapewniają autorzy, są wyjątkowym przekazem historycznych faktów, bez zrozumienia których dzisiejsze pojednanie z Niemcami (w ramach UE i dobrosąsiedzkiej współpracy) byłoby niemożliwe. Książka ukazała się w 75. rocznicę wybuchu II wojny światowej. Swoje artykuły napisali zwykli ludzie i artyści, pisarze, ksiądz katolicki, nauczyciel, profesorowie wyższych uczelni. Po każdym tekście jest notka o jego autorze. Jak zapewnia Karol Czejarek czyta się tę książkę jak powieść. Swój pogląd na kwestię przebaczenia i pojednania wyraził słowami:

Niemcy, to dzisiaj inny niż przed 65 laty kraj, to przede wszystkim modelowa demokracja rzetelnie budowana od podstaw. Państwo to jest dzisiaj nie tylko największym partnerem handlowym Polski, ale też aktywnie popierało starania Polski o uzyskanie członkostwa w UE, przyczyniło się do przyznania jej środków z budżetu UE na lata 2006-2013 i 2014-2020, dzięki czemu Polska nie tylko odrobiła dystans cywilizacyjny, lecz aspiruje dzisiaj do krajów najbardziej rozwiniętych w świecie ${ }^{35}$.

W 2017 roku opublikowano Historię pamięcia pisana. Biografie polskoniemieckie (cz. II) ${ }^{36}$, gdzie zawarto 29 przejmujących biografii autorów polskich i niemieckich. Wśród wielu wspomnień są wspomnienia autorów, którzy pochodzą ze Szczecina, bądź mieli styczność z naszym miastem ${ }^{37}$.

Rozważania o tej publikacji można zamknąć cytatem Haliny Stano (1954) z Warszawy, która swój krótki tekst kończy słowami: „Historia pamięcią pisana

\footnotetext{
${ }^{34}$ Historia pamięcia pisana. Biografie polsko-niemieckie, cz. 1, red. K. Czejarek, K. Garczewski, wstęp K. Czejarek, współpraca nauk. T.G. Pszczółkowski, red. wersji niem. A. Warakomska, Pułtusk 2014 (książka zawiera 333 s. po polsku i 333 s. po niemiecku).

${ }^{35}$ Tamże.

${ }^{36}$ Historia pamięcia pisana. Biografie polsko-niemieckie, cz. 2, red. K. Czejarek, T.G. Pszczółkowski, Pułtusk 2017 (książka zawiera 447 s. po polsku i 486 s. po niemiecku).

37 Tamże; m.in. wspomnienia Antoniny Abramiuk (ur. we Francji) obecnie mieszkającej w Szczecinie, s. 39-47 i Michała Władysława Kulika, s. 189-192.
} 
i konfrontowana, to według mnie klucz do otwierania zamkniętych drzwi, poznawania swoich nadziei i lęków oraz do porozumienia i współistnienia"38.

Dzieci Karola Czejarka podążają podobną drogą. Syn Roman jest dziennikarzem, prezenterem radiowym, autorem licznych wydawnictw o Szczecinie i Pomorzu Zachodnim, córka Anna jest historykiem sztuki, a syn Hubert, absolwent Katedry Języków Obcych (UW), jest także tłumaczem.

Konkludując, twórczość Karola Czejarka jest inspiracją do dalszych badań nad problemami wypędzenia i przesiedlenia, nad kwestią mieszanych małżeństw oraz czynienia wysiłków w kierunku polsko-niemieckiego pojednania. Być może bohater tego artykułu będzie dla młodych ludzi inspirującym przykładem do dalszych poszukiwań i do utrwalania pamięci o dawnych twórcach, którzy działali na Pomorzu Zachodnim.

Karol Czejarek ma jeszcze jedno marzenie - pragnie zainicjować badania porównawcze na temat kultury pamięci o Polsce i Niemczech.

\section{Bibliografia}

„Gazeta Wyborcza, Magazyn Szczeciński”, 4.04.2014.

„Kurier Szczeciński”, 4.08.1965.

Czech-Sobczak M., Kuruś-Brzeziński W., Szczecińscy filharmonicy - artyści muzycy, Szczecin 2000.

Czejarek K., Anna Seghers, Poznań 1986.

Czejarek K., Hans Helmut Kirst (13.11.2017), www.pisarze.pl.

Czejarek K., Historia pamięcia pisana. Biografie polsko-niemieckie, cz. 1, Pułtusk 2014.

Czejarek K., Historia pamięcia pisana. Biografie polsko-niemieckie, cz. 2, Pułtusk 2017.

Czejarek K., Krzysztof Kostyrko - wielki Czlowiek kultury, www.pisarze.pl (dostęp 11.12.2017).

Czejarek K., Nazizm, wojna i III Rzesza w powieściach Hansa Hellmuta Kirsta, Wroclaw 2003.

Czejarek K., Spotkanie kolarskich pokoleń w Szczecinie, przegląddziennikarski.pl, 8.06.2019.

Czejarek K., Wspomnienia o moim ojcu. Wojna, wypędzenie, pojednanie polsko-niemieckie, ,Przegląd Dziennikarski”, 2.12.2017.

Czejarek K., Tadeusz Kaczmarek, b. wiceminister kultury i sztuki (1972-1978), „Przegląd Dziennikarski”, 5.05.2018.

${ }^{38}$ Tamże, H. Stanio, Poszukiwanie prawdy o Niemczech, s. 281-283. 
Czterdziestopięciolecie Szczecińskiego Towarzystwa Kultury. Materiaty na XI Sejmik, Szczecin 2009.

Encyklopedia Szczecina. Wydanie jubileuszowe z okazji 75-lecia polskiego Szczecina, Szczecin 2015.

Hans Hellmut Kirst, https://wikipedia.org/wiki/Hans_Hellmut_Kirst (dostęp 20.03.2019).

Hussak T., Dorobek ksztatcenia księgarzy. 60 lat istnienia szkót księgarskich, Warszawa 2010.

Kotarba M., „Dogonić uciekający świat”, Rozmowa z Karolem Czejarkiem na temat stanu ksztatcenia językowego (28.02.2008), https://edukator.ore.edu.pl/dogoni-uciekajcy-wiat-rozmowa-z (dostęp 20.04.2019).

Kozłowski K., Życie kulturalne Szczecina w latach 1945-1980. Szkic historyczny, Szczecin 1994.

Pamiętnikarstwo na Pomorzu Zachodnim. Czterdziestolecie konkursu „Dzieje szczecińskich rodzin", red. T. Białecki, K. Kozłowski, A. Derbisz, S. Krzywicki, U. Rosłaniec, Szczecin 2009.

Polska między Niemcami a Rosja - Polen zwischen Deutschland und Russland, Materiaty z międzynarodowych kolokwiów/Materialien internationaler collequien, red. $\mathrm{K}$. Czejarek, T.G. Pszczółkowski, Pułtusk 2011.

Przegląd Dziennikarski, https://przegladdziennikarski.pl/autor/karolczejarek.

Rogaliński P., Wywiad z prof. Karolem Czejarkiem „Polacy są na siebie skazani” (19.07.2017), https://przegladdziennkarski.pl/polacy-i-niemcy-sa -na-siebie-skazani (dostęp 17.03.2019).

Tadeusz Hussak, https://wikipedia.org/wiki/Tadeusz_Hussak (dostęp 17.03.2019).

Zaleska Z., Przejęzyczenie. Rozmowy o przekładzie, Wołowiec 2016.

ZPwN, Wikipedia/poloniaviva.eu/index.php/pl/organizacje/1556-rodlo (dostęp 14.03.2019).

\section{Abstrakt}

Działalność Karola Czejarka - księgarza, organizatora i współorganizatora instytucji kultury oraz społecznego ruchu kulturalnego na Pomorzu Zachodnim, germanisty, autora licznych publikacji - zasługuje na szczególną uwagę. Mieszkał on w Szczecinie w latach 1948-1973, był księgarzem i animatorem kultury na Pomorzu Zachodnim, kolarzem z osiągnięciami, germanistą, doktorem nauk humanistycznych Uniwersytetu Szczecińskiego, profesorem nadzwyczajnym Akademii Humanistycznej im. Aleksandra Gieysztora w Pułtusku, emerytowanym pracownikiem naukowo-dydaktycznym Instytutu Lingwistyki Stosowanej Uniwersytetu Warszawskiego, autorem, redaktorem i współredaktorem wielu publikacji. 
W artykule oceniono pracę zawodową i naukową Karola Czejarka, jego zainteresowania, dokonania translatorskie oraz działania na rzecz pojednania i współpracy polsko-niemieckiej.

Karol Czejarek - wnuk Karola Czejarka, śląskiego Polaka mieszkającego w Zabrzu, wówczas (Hindenburg), syn Romana Czejarka i Marie Czejarek z d. Mellin - urodził się 12 sierpnia 1939 roku w Berlinie. Jego rodzice podczas II wojny światowej doświadczyli przykrego losu przesiedlenia z rodzinnego Zabrza, a potem ponownego przesiedlenia (wypędzenia) z Berlina. Karol jest przykładem losu dziecka przesiedlonego i dziecka dorastającego w powojennym Szczecinie. Po stracie ojca (zmarł w 1953 r. w Szczecinie) oraz matki (jako Niemka nie mogła dostać pracy i wraz z trzynastoletnią córką Annemarie w 1957 r. wyjechała do rodzinnego miasteczka Ahrbergen, pomiędzy Hanowerem a Hildesheim) - pozostał sam. Był uczniem II Liceum Ogólnokształcącego im. Mieszka I w Szczecinie. Ucząc się, podejmował się różnych prac, żeby móc przeżyć. Nauką, zdolnościami, wytrwałością i ciężką pracą na rzecz rozwoju kultury dochodził po szczeblach rozwoju zawodowego do coraz lepszych stanowisk w Ministerstwie Kultury, by następnie zając się pracą dydaktyczną i naukową.

Karol Czejarek jest tłumaczem na język polski książek wielu wybitnych pisarzy niemieckich. Szczególnym sentymentem darzy twórczość Hansa Helmuta Kirsta, byłego nazisty, który jako pierwszy odsłonił nazizm, obnażając metody stosowane przez brutalna politykę Hitlera i przestrzegając przed jej nawrotem. I to jemu głównie poświęcił swój czas tłumacząc jego Dzieła zebrane obejmujące ponad 40 tomów.

Własne doświadczenia Karola Czejarka, a przede wszystkim krzywdy wyrządzone Polakom przez nazistów podczas II wojny światowej ukierunkowały zapewne jego zainteresowania germanistyką, lingwistyką stosowaną i badaniami nad kwestiami wypędzenia i przesiedlenia oraz problemami małżeństw mieszanych. Czynił wysiłki w kierunku polsko-niemieckiego pojednania i współpracy kulturalnej pomiędzy tymi narodami - w nadziei, że okrutna historia więcej się nie powtórzy. Owocem tej współpracy jest m.in. publikacja pod red. Karola Czejarka, Tomasza G. Pszczółkowskiego i przy udziale Axela Schmidta-Gödelitza Historia pamięcia pisana. Biografie polsko-niemieckie, cz. 1 i cz. 2. Postawa prof. Karola Czejarka jest wzorem do naśladowania, a przytoczone w artykule fragmenty jego tekstów i tekstów innych autorów dowodzą, że nie należy żyć tylko przeszłością, ale iść do przodu i budować wspólną przyszłość. 


\title{
The Activities of Karol Czejarek, a Bookseller, Co-organiser of the Sociocultural Movement and Its Institutions in West Pomerania, Germanist, and Author of Numerous Publications
}

\begin{abstract}
Działalność Karola Czejarka - ksieggarza, organizatora i współorganizatora instytucji oraz społecznego ruchu kulturalnego na Pomorzu Zachodnim, germanisty, autora licznych publikacji [»The Activities of Karol Czejarek, a Bookseller, Co-Organiser of the Sociocultural Movement and its Institutions in West Pomerania, Germanist, and Author of Numerous Publications «] - it is almost a monograph presenting Professor Karol Czejarek, who lived in Szczecin in the years 1948-1973. He was a bookseller and animateur of culture in West Pomerania, a cyclist with achievements, Germanist, doctor of Humanities of Szczecin University, professor extraordinarius of the Aleksander-Gieysztor Academy of Humanities in Pułtusk, retired research worker and lecturer of the Institute of Applied Linguistics of Warsaw University, writer and editor.

The article contains an appraisal of Karol Czejarek's professional and academic work, and presents his interests, translations and activities on behalf of the reconciliation between Poland and Germany.
\end{abstract}

Karol Czejarek, a grandson of Karol Czejarek, a Silesian Pole who lived in Zabrze (at that time called Hindenburg), and a son of Roman Czejarek and Maria Czejarek de domo Mellin, was born on August 12, 1939 in Berlin. During the Second World War his parents had bitter experience of relocation from their native Zabrze, and later expulsion from Berlin. Karol, who was then 8 years old, is an example of the fate of a child first relocated and later growing up in the post-war Szczecin. In 1953 his father died (in Szczecin), then he also lost his mother, who being German could not find a job and with the three-year-old Karol's sister, Annemarie, in 1957 left for her native Ahrbergen, somewhere between Hannover and Hildeshaim, and Karol, a pupil of the Mieszko I Lycée no 2 in Szczecin, was left alone. In order to survived he had to take odd jobs.

Thanks to his abilities and hard work he kept moving up consecutive rungs of his career to achieve senior posts in the Ministry of Culture, and later to devote himself to academic career.

Karol Czejarek is a translator of books written by many outstanding German writers into Polish. His favourite writer is Hans Hellmut Kirst, who had been a Nazi, but later was the first to reveal the true nature of Nazism and the brutal methods of Hitler's policy, and he warned against its return. Karol Czejarek translated the 40-volume Collective Works written by Kirst.

Karol Czejarek's own experiences, first of all concerning the harm caused to the Poles by the Nazis during the Second World War, must have shaped his interest in 
German studies, applied linguistics and research into relocation and expulsion of population groups, mixed marriages, and prospects of Polish-German reconciliation and cultural cooperation between those two nations, so that the cruel past would never happen again. An example of that cooperation is a publication edited by Karol Czejarek, Tomasz G. Pszczółkowski and Axel Schmidt-Gödelitz entitled Historia pamięcia pisana. Biografie polsko-niemieckie [»History Written with Memory. Polish-German Biographies«], Part 1 (2014) and Part 2 (2017).

The conduct of Karol Czejarek is an exemplary behaviour, and the quotations written by many authors included in the text of the article confirm the thesis that we should not concentrate only on the past, but go forwards and build a new reality. 